\title{
Watch Your Neighbor: A Volatility Spillover in ASEAN-5 Stock Exchange
}

\author{
Sumani' $^{1}$ Siti Saadah ${ }^{2}$ \\ 1,2Prodi Manajemen, Fakultas Ekonomi dan Bisnis, Universitas Katolik Indonesia Atma Jaya \\ Jln. Jend. Sudirman No.51, Jakarta Selatan 12930, Indonesia \\ ${ }^{1}$ sumani@atmajaya.ac.id; ${ }^{2}$ siti.saadah@atmajaya.ac.id
}

Received: $4^{\text {th }}$ February 2019/ Revised: $22^{\text {nd }}$ April 2019/ Accepted: $6^{\text {th }}$ May 2019

How to Cite: Sumani, \& Saadah, S. (2019). Watch Your Neighbor: A Volatility Spillover in ASEAN-5 Stock Exchange. Binus Business Review, 10(1), 59-65. https://doi.org/10.21512/bbr.v10i1.5400

\begin{abstract}
In the process of financial markets integration, this research was conducted to investigate the phenomenon of the transmission of stock return volatility among stock market in five ASEAN countries. Those were Indonesia, Singapore, Malaysia, Philippines, and Thailand. The research was important because when the interdependence of financial markets had increased, changes in asset prices in the market were not only influenced by the shock in the market but also by its response to asset price volatility that occurred in other countries. Information about the volatility spillover between markets was important for investors to the portfolio selection process. Exponential Generalized Autoregressive Conditional Heteroskedasticity (EGARCH) method was used on a daily time series stock return data obtained by accessing www.bloomberg.com. The result indicates that the shock in Singapore, Malaysia, Thailand, and the Philippines stock market will be transmitted to the Indonesia Stock Market with an asymmetric pattern. It has increased intensity after the implementation of the ASEAN Economic Community in December 2015.
\end{abstract}

Keywords: Volatility pattern, ASEAN, stock market

\section{INTRODUCTION}

Various countries currently undertake the phenomenon of financial integration which is closely related to the liberalization efforts. In a broad sense, financial liberalization is a series of processes aiming at reducing restrictions on the relationship between the states of the financial system. One of the main frameworks of the ASEAN Economic Community (AEC) is to make ASEAN as a single market. It is not only based on a single production which there is a free flow of goods, services, investment, and skilled labor, but capital also flows more freely among member countries. In the AEC blueprint, liberalization of capital flows in ASEAN is intended to encourage the flow of investment and international trade, efficient capital placement, and financial market developments. There are two efforts to create more free capital flows among ASEAN countries. First, it is by strengthening the development and integration of the ASEAN capital market. Second, it increases the flow of capital in the region through a process of liberalization. The integration, which is the implication of the process of financial liberalization, leads to cross-border capital flow between countries more freely.

In addition to the expected benefits of this liberalization process and positive impact on the financial market developments, financial integration can increase financial risks and threaten the stability of economic conditions in a country. Beck, Claessens, and Schmukler (2013) stated that when a country was connected with another state or the global financial system, the shock occurring in another country would threaten financial stability. In the era of an integrated market and the openness of capital flows, inter-dependencies among financial markets are increasing. Previous researchers find that there is strong interdependence among the stock markets. It is considered due to technological development and financial deregulations of financial markets ( $\mathrm{Li}$ \& Giles, 2015; Jan \& Jebran, 2015; Jebran, 2014). Most recently, Jebran, Chen, Ullah, and Mirza (2017) and Jebran and Iqbal (2016b) studied the Asian stock markets and found linkages among the markets. 
The impact of this interdependency is that the financial markets in a country will have a higher vulnerability to shocks in financial markets of other countries. A subprime mortgage caused the global economic crisis in 2008 that started from the US market crash. In rapid time, it spread to most parts of the world, especially developed countries that are economically and financially integrated with the US (Vieira, 2011). Many of researchers focus on studying the interdependency among financial markets such as Jebran (2014), Jan and Jebran (2015), Jebran and Iqbal, (2016a), and Islam, Islam, and Siddiqui (2014). They investigated the volatility spillover effect among the developed and emerging market. They found that local markets were integrated with the regional and global markets. Moreover, the volatility spillover effect from the global markets was greater than the regional market.

Then, Bae and Zhang (2015) mentioned that spillover effects had a disruptive effect if it occurred in crisis period. They suggested two possible reasons for financial loss in a crisis. First, it was the sudden outflow of money by foreign investors, because they could easily leave integrated markets. Second, the risk exposure as the integrated market would likely to face bigger loss due to financial contagion in a crisis.

The incidence of transmission of the financial crisis is often not related to the fundamental conditions of a country. However, in the era of globalization, the market and economy among countries become increasingly integrated and interconnected to one another. When shock happens in a country, it is easily transmitted to other countries. The massive and longlasting effect of 2008 subprime is probably due to increased stock market integration (Srivastava, Bhatia, \& Gupta, 2015).

In such situations, efforts to gain a better understanding of international transmission in shock and inter-market volatility are important, especially accompanying the ever-increasing process of economic and financial integration. This is within the framework of maintaining financial system stability in the economy of a country. The information about linkages between the emerging markets will also provide valuable information to investors, which may help in portfolio formulation (Li \& Giles, 2015).

Financial liberalization undertaken by various countries causes the financial system of a country to be more connected and integrated with the global financial system. This is what causes the integration in financial markets to show a correlation between market returns and volatility. In the context of the ASEAN capital market integration efforts, this can result in volatility/return movements in one capital markets. Then, it will be associated with volatility/ return movements in other markets (Atje \& Titiheruw, 2016; ASEAN, 2015).

Many empirical studies have been carried out in line with the increasing integration of financial markets among countries as a result of the liberalization process adopted by many countries. Saadah (2013) revealed that significant empirical evidence of shock/return volatility on the Singapore Stock Exchange would soon be transmitted to the Indonesian stock market. Spillover patterns detected had two patterns which form an asymmetric pattern. First, transmission shock/ return volatility of the Singapore Stock Exchange to the Indonesia Stock Exchange became stronger when Singapore Stock Exchange experienced a negative return compared to a positive return. Second, the transmission of the shock was stronger Singapore Stock Exchange was in phase, and the trend was declining (the market was in a bearish phase).

The process of financial integration is increasing in intensity. Then, the efforts to investigate the transmission of shock and return volatility between markets become essential. One of the important reasons is that the transmission of shock and return volatility will be a source of financial contagion. When this contagion phenomenon occurs, the macro policy is indispensable in responding to external market movements if the market begins declining. This is very important to guarantee the stability of the national financial system. Another important reason is the interdependence of financial markets increases. The asset prices in one market to other markets will be interconnected. In such conditions, analyzing the single market without considering the aspects of another market means ignoring important information about market behavior. Changes in asset prices in the market are not only affected by the volatility shock in the market but also by the response to asset price volatility in other countries. An understanding of the volatility spillover between these markets will have implications on daily essentials such as risk management and the process of portfolio selection by the investors.

Along with the increase in the implementation of the AEC blueprint among member countries of ASEAN, this research aims to investigate the phenomenon of transmission or spillover of volatility between stock markets countries that are included in this region (ASEAN-5). Those are Indonesia, Malaysia, Philippines, Singapore, and Thailand. In particular, the researchers will analyze whether there is a significant increase in the intensity of this volatility spillover after the official implementation of the AEC in 2015.

The investigation of volatility movement in this research will provide an overview of how the patterns of transmission of shock in the financial system of intra-ASEAN countries. The information about how the turmoil in the market will be transmitted to the financial markets in other countries is important. This information will also be necessary for investment decisions in the global market.

\section{METHODS}

This explanatory research uses time series data of the daily closing price of the stock price ASEAN-5 index. The sample period is from January 3, 2012, till 
September 9, 2016. The sample is selected because the researchers want to examine the impact of the AEC after the implementation at the end of 2015. The election of the five countries as the sample because of economic relations and capital flows in ASEAN-5. Since 2008, it has shown an increasing trend, and in the ASEAN market, it is dominated by the five countries. The undeveloped capital market in other ASEAN countries outside ASEAN-5 is also another reason for the selection of ASEAN-5 countries.

The analysis of volatility spillover will not be done by combining all the data of the five countries simultaneously. However, it can be done by pairing data for two countries. The absent of examination of volatility spillover into one model simultaneously is because of differences in the exchange time of each country. Combination of five overall lead investigators to waste many data in this research. The ejection of time sample data is too much for this research. It means losing important information of high characteristic frequency in the actual data.

Daily time series data for the stock price index ASEAN 5 countries are obtained from www. bloomberg.com. For each index, the daily return is calculated as the change in the logarithm of closing prices for two consecutive days: $R_{t}=\ln \left(S_{t}\right)-\ln \left(S_{t-1}\right)$, with St is closing price index on $t$ day.

The investigation on volatility spillover will be done by applying a model Exponential Generalized Autoregressive Conditional Heteroskedasticity (EGARCH). It is an extension of Generalized Autoregressive Conditional Heteroskedas-ticity (GARCH) which can accommodate asymmetric transmission patterns. The good news or bad news affect the market implications of asymmetric against the volatility of return. In general, according to Brooks (2014), when the negative news is in the market, asset prices will tend to enter a phase of turbulence and volatility increases. However, if the positive news comes to the market, volatility tends to decline, and the market enters the tranquil phase. EGARCH model specification is in Equation (1) and (2).

$$
y_{t}=\mu+u_{t} \quad u_{t} \approx N\left(0, \sigma_{t}^{2}\right)
$$

$$
\begin{aligned}
& \ln \left(\sigma_{t}^{2}\right)=\omega+\beta \ln \left(\sigma_{t-1}^{2}\right)+\gamma \frac{u_{t-1}}{\sqrt{\sigma_{t-1}^{2}}}+\alpha\left[\frac{\left|u_{t-1}\right|}{\sqrt{\sigma_{t-1}^{2}}}-\sqrt{\frac{2}{\pi}}\right] \\
& \text { if } \frac{u_{t-1}}{\sqrt{\sigma_{t-1}^{2}}}=\eta_{t-1} \\
& \ln \left(\sigma_{t}^{2}\right)=\omega+\beta \ln \left(\sigma_{t-1}^{2}\right)+\gamma \eta_{t-1}+\alpha\left[\left|\eta_{t-1}\right|-\sqrt{\frac{2}{\pi}}\right] \\
& \eta_{t-1}+\alpha\left[\left|\eta_{t-1}\right|-\sqrt{\frac{2}{\pi}}\right]= \begin{cases}(\gamma+\alpha) \eta_{t-1}-\alpha \sqrt{2 / \pi} & \text { if } \eta_{t-1} \geq 0 \\
(\gamma-\alpha) \eta_{t-1}-\alpha \sqrt{2 / \pi} & \text { if } \eta_{t-1}<0\end{cases}
\end{aligned}
$$

Parameters $(\gamma+\alpha)$ and $(\gamma-\alpha)$ in the reflect the nature of the response of asymmetry volatility to positive and negative shocks. If it is $\gamma<0$, positive return shock will increase the volatility smaller than the negative shocks with the same magnitude. For another advantage of this model, the parameters are not the subject to the non-negativity constraint as in the standard GARCH model.

Identification of volatility spillover between markets is made by modifying the Equation (2). Components in lag squared errors resulting from the modeling of the market will be put on EGARCH models for other markets as an explanatory variable in the equation of conditional variance. Thus, the spillover effect of the B market against A market can be accommodated within the following specifications:

$$
\begin{aligned}
& \ln \left(\sigma_{t}^{2}\right)=\omega+\beta \ln \left(\sigma_{t-1}^{2}\right)+\gamma \frac{u_{t-1}}{\sqrt{\sigma_{t-1}^{2}}}+\alpha\left[\frac{\left|u_{t-1}\right|}{\sqrt{\sigma_{t-1}^{2}}}-\sqrt{\frac{2}{\pi}}\right]+\delta_{1} \mathrm{~h} \varepsilon(B)_{t}^{2}+\delta_{2} \mathrm{~h} \varepsilon(B)_{t}^{2} D_{t} \\
& D_{t}=\left\{\begin{array}{cc}
0 & \text { for period before AEC implementation } \\
1 & \text { for period after AEC implementation }
\end{array}\right.
\end{aligned}
$$

It shows that $\varepsilon(B)_{t}^{2}$ as a shock that occurs in the $\mathrm{B}$ market. Then, the coefficient $(\delta 1)$ is the parameter to measure the impact of the shock/volatility return from B stock market on conditional volatility return to A stock market. Meanwhile, $\varepsilon(B)_{t}^{2} D$ is the interaction between the dummy variable and the shock occurring in the B market. The parameter $(\delta 2)$ will measure the magnitude of the difference in intensity of spillover in the period before the dealing with the aftermath of the AEC implementation agreement. Then, data analysis in this research is carried out using software E-Views 9.

\section{RESULTS AND DISCUSSIONS}

EGARCH is an appropriate model for data that have a time-varying volatility nature. The examination of the existence of ARCH effects in Table 1 shows that there is an ARCH effect in residual of Jakarta Composite Index (JCI) stock return.

Table 1 ARCH Effect Test of JCI

\begin{tabular}{llll}
\hline Statistic & \multicolumn{3}{l}{ P-value } \\
\hline F-Statistic & 47,71171 & Prob.F(1,1121) & 0,0000 \\
Obs*R-squared & 45,84557 & Prob. ChiSquare (1) & 0,0000 \\
\hline
\end{tabular}

Source: Data Processing Results

Thus, EGARCH is the right model for modeling the behavior of stock returns in JCI because it shows heteroskedastic characteristic. The results of EGARCH investigate the spillover of volatility/shock occurring in Singapore Stock Exchange to Indonesia Stock Exchange. The result can be seen in Table 2. 
Table 2 Volatility Spillover from Singapore Stock Exchange

\begin{tabular}{lccc}
\hline & Coeffcient & z-statistic & Prob \\
\hline $\begin{array}{l}\text { Mean equation } \\
\text { Constant }(\mu)\end{array}$ & 0,000400 & 1,538949 & 0,1238 \\
Variance equation & & & \\
Constant $(\omega)$ & $-0,265566$ & $-3,059777$ & 0,0022 \\
GARCH effect $(\beta)$ & 0,957861 & 99,68253 & 0,0000 \\
Asymmetry (negative & $-0,062401$ & $-4,275806$ & 0,0000 \\
return shock) - $(\gamma)$ & & & \\
Volatility spillover $\left(\delta_{P}\right)$ & 0,019871 & 3,602767 & 0,0003 \\
$\begin{array}{l}\text { Asymmetry volatility } \\
\text { spillover }(\text { pre and post- }\end{array}$ & 0,003082 & 2,393567 & 0,0167 \\
AEC) $-\left(\delta_{2}\right)$ & & & \\
\hline
\end{tabular}

(Source: Data Processing Results)

Table 3 Residual Variance Testing Results

\begin{tabular}{llll}
\hline Statistic & \multicolumn{3}{c}{ P-value } \\
\hline F-Statistic & 0,590633 & Prob.F(1,1121) & 0,4423 \\
Obs*R-squared & 0,591376 & Prob. ChiSquare (1) & 0,4419 \\
\hline
\end{tabular}

(Source: Data Processing Results)

Moreover, $\delta$ parameter in the model estimation results in Table 2 also shows the significant volatility spillover. Shock in return volatility in the Singapore Stock Exchange will be immediately transmitted to the Indonesia Stock Exchange. This finding is consistent with Saadah (2013). The researcher indicated the existence of volatility spillover from Singapore Stock Exchange to Indonesia Stock Exchange. The new and interesting finding from this research compared to the previous research is the intensity of transmission. It becomes higher in the period after the implementation of AEC agreement in December 2015. It can be seen from the $\delta$, parameter that is positive and significant (at $\alpha=5 \%$ ).

Table 3 presents the results of testing the residuals from modeling EGARCH for JCI return data in Table 2. Prob Chi-Square of 0,4419 indicates that the residual from the EGARCH modeling has shown homoscedasticity traits. The significant positive sign of $\beta$ parameter shows the impact of news on the return volatility in JCI. It indicates the nature of persistent throughout the analysis period. The estimation results in Table 2 also indicate the presence of significant statistical evidence to support the hypothesis leverage effect that the bad news (negative shock) have a significant impact on the volatility of returns compared to good news (positive shocks). This asymmetry pattern can be seen from the $\gamma$ parameter that is negative and significant.
Table 4 Volatility Spillover from Malaysia Stock Exchange

\begin{tabular}{lccc}
\hline & Coeffcient & z-statistic & Prob \\
\hline Mean equation & & & \\
Constant $(\mu)$ & 0,000357 & 1,314531 & 0,1887 \\
Variance equation & & & \\
Constant $(\omega)$ & $-0,266304$ & $-3,239007$ & 0,0012 \\
GARCH effect $(\beta)$ & 0,965234 & 109,9908 & 0,0000 \\
Asymmetry (negative & $-0,065015$ & $-4,715707$ & 0,0000 \\
return shock) - $(\gamma)$ & & & \\
Volatility spillover $\left(\delta_{\nu}\right)$ & 0,012679 & 2,758512 & 0,0058 \\
Asymmetry volatility & 0,001547 & 1,659643 & 0,0970 \\
spillover $($ pre and post- & & & \\
AEC) $-\left(\delta_{2}\right)$ & & & \\
\hline
\end{tabular}

(Source: Data Processing Results)

Table 5 Residual Variance Testing Results

\begin{tabular}{llll}
\hline Statistic & \multicolumn{3}{l}{ P-value } \\
\hline F-Statistic & 2,150052 & Prob.F(1,1104) & 0,1428 \\
Obs*R- & 2,149760 & $\begin{array}{l}\text { Prob. ChiSquare } \\
\text { squared }\end{array}$ & 0,1426 \\
\hline
\end{tabular}

(Source: Data Processing Results)

Moreover, the results of EGARCH in investigating the spillover of volatility from the stock exchange of Malaysia to the Indonesian stock market are shown in Table 4 . Then, $\delta_{l}$ parameters in the model estimation results in Table 4 show the significant volatility spillover. Shock/return volatility that occurs on the Malaysian and Singapore Stock Exchange will be immediately transmitted to the Indonesian Stock Exchange. However, at the significance level $\alpha=5 \%$, there is no significant difference in intensity spillover in the period before and after the implementation of the agreement AEC. It can be seen from the insignificant $\delta_{2}$ parameter.

As in Table 3, Table 5 displays the results of testing the residuals modeling EGARCH for JCI return data in Table 4. Prob Chi-Square of 0,1426 indicates that EGARCH modeling has shown the homoscedastic characteristics. This affirms the findings among Singapore and Indonesia Stock Exchange, the positive and significant $\beta$ parameter and negative and significant $\gamma$ parameters show that the impact of news on volatility return JCI exhibits is not only persistent throughout the analysis period, but it also shows an asymmetry pattern.

Next, it is the results of model estimation EGARCH to investigate the spillover of volatility shock that occurred in Thailand Stock Exchange on the Indonesia Stock Exchange. The result is shown in Table 6. 
Table 6 Volatility Spillover from Thailand Stock Exchange

\begin{tabular}{lccc}
\hline & Coeffcient & z-statistic & Prob \\
\hline Mean equation & & & \\
Constant $(\mu)$ & 0,000382 & 1,411609 & 0,1581 \\
Variance equation & & & \\
Constant $(\omega)$ & $-0,236353$ & $-4,099672$ & 0,0000 \\
GARCH effect $(\beta)$ & 0,968520 & 150,9036 & 0,0000 \\
Asymmetry (negative & & & \\
return shock) - $(\gamma)$ & $-0,068666$ & $-4,850351$ & 0,0000 \\
$\begin{array}{l}\text { Volatility spillover }\left(\delta_{\nu}\right) \\
\text { Asymmetry volatility }\end{array}$ & 0,014014 & 3,817630 & 0,0001 \\
spillover $($ pre and post- & & & \\
AEC) $-\left(\delta_{2}\right)$ & 0,000809 & 0,932670 & 0,3510 \\
\hline
\end{tabular}

(Source: Data Processing Results)

Table 7 Residual Variance Testing Results

\begin{tabular}{llll}
\hline Statistic & \multicolumn{3}{l}{ P-value } \\
\hline F-Statistic & 0,033330 & Prob.F(1,1066) & 0,8552 \\
Obs*R-squared & 0,033391 & Prob. ChiSquare (1) & 0,8550 \\
\hline
\end{tabular}

(Source: Data Processing Results)

Then, $\delta$ parameters in the model estimation results in Table 6 also shows that a significant volatility spillover occurs not only from Singapore and Malaysia Stock Exchanges but also from the Thailand Stock Exchange. Shock/return volatility on Thailand Stock Exchange can affect Indonesia Stock Exchange. However, the transmission of the volatility of the Malaysian Stock Exchange until the period of September 2016 and the intensity of the spillover from Thailand Stock Exchange have not shown a significant increase from the period prior to the implementation of AEC. It can be seen of parameter $\delta$, that is positive, but it is not significant (at $\alpha=5 \%$ ).

Prob Chi-Square of 0,8552 in Table 7 shows that EGARCH model in Table 6 is an appropriate model. It is because the residual resulting from the model show homoscedastic characteristics. The positive and significant parameters and negative and significant parameters in Tables 2, 4, and 6 show that the impact of news on volatility JCI return has persistent nature and asymmetry pattern.

Next, the results of EGARCH to investigate the spillover of volatility shock that occurred in the Philippines Stock Market to the Indonesian Stock Market is shown in Table 8. The $\delta$, parameters in the model estimation results in Table 8 indicate that the Indonesian Stock Exchange is not only affected by the transmission of the volatility of Singapore, Malaysia, and Thailand Stock Exchanges but also by Philipines Stock Exchange. However, there is a difference in the transmission pattern from Malaysia and Thailand. It is in the period after the implementation of AEC.
The transmission of the volatility of the Philippines Stock Exchange spillover is increased significantly compared to the period before the implementation of $\mathrm{AEC}$. It can be seen of parameter $\delta$, that is positive and significant (at $\alpha=5 \%$ ).

Table 8 Volatility Spillover from Philippines Stock Exchange

\begin{tabular}{lccc}
\hline & Coeffcient & z-statistic & Prob \\
\hline Mean equation & & & \\
Constant $(\mu)$ & 0,000434 & 1,598411 & 0,1100 \\
Variance equation & & & \\
Constant $(\omega)$ & $-0,758830$ & $-4,201068$ & 0,0000 \\
GARCH effect $(\beta)$ & 0,843028 & 36,27225 & 0,0000 \\
Asymmetry $($ negative & $-0,082171$ & $-4,030113$ & 0,0001 \\
return shock) - $(\gamma)$ & & & \\
Volatility spillover $\left(\delta_{\nu}\right)$ & 0,078704 & 8,325679 & 0,0000 \\
Asymmetry volatility & 0,006279 & 2,437557 & 0,0148 \\
spillover $($ pre and post- & & & \\
AEC) $-\left(\delta_{2}\right)$ & & & \\
\hline
\end{tabular}

(Source: Data Processing Results)

Table 9 Residual Variance Testing Results

\begin{tabular}{llll}
\hline Statistic & \multicolumn{3}{l}{ P-value } \\
\hline F-Statistic & 0,004035 & Prob.F(1,1094) & 0,9494 \\
Obs*R-squared & 0,004042 & Prob. ChiSquare (1) & 0,9493 \\
\hline
\end{tabular}

(Source: Data Processing Results)

Table 9 displays the result of residual testing by using EGARCH for JCI return data in Table 8. The residuals from EGARCH show the homoscedastic characteristic. The result of the model estimation in Table 8 shows positive and significant $\beta$ parameters and negative and significant $\gamma$ parameters. In addition to showing persistent nature, those parameters imply that the impact of news to return volatility of JCI has characteristics as stated in the hypothesis leverage effect.

The estimation results of the model in Table 2, 4,6 , and 8 indicate that there is statistical evidence. It is sufficient to state that there is the existence of significant spillover between ASEAN-5 Stock Exchanges (Singapore, Malaysia, Thailand, and Philippines) to Indonesia Stock Exchange. These empirical findings are shown in Table 10.

These findings indicate that shock happened in the four countries will be immediately transmitted to Indonesia Stock Market. The shock from Singapore, Malaysia, and Philippines Stock Exchanges and the intensity of spillover to the Indonesia Stock Market showed a significant increase after the implementation of AEC 
Table 10 ASEAN Stock Market Volatility Spillover

\begin{tabular}{lccc}
\hline & \multicolumn{3}{c}{ Parameter } \\
\hline & $\begin{array}{c}\text { Volatility } \\
\text { Spillover }\end{array}$ & \multicolumn{2}{c}{ Asymmetry } \\
\cline { 3 - 4 } & & $\begin{array}{c}\text { Negative Shock } \\
\text { Return }\end{array}$ & $\begin{array}{c}\text { Pre \& Post } \\
\text { AEC }\end{array}$ \\
\hline Singapore & $0,019871^{*}$ & $-0,062401^{*}$ & $0,003082^{*}$ \\
Malaysia & $0,012679^{*}$ & $-0,065015^{*}$ & $0,001547^{*}$ \\
Thailand & $0,014014^{*}$ & $-0,068666^{*}$ & 0,000809 \\
Philipine & $0,078704^{*}$ & $-0,082171^{*}$ & $0,006279^{*}$ \\
\hline
\end{tabular}

Information : *) significant at $\alpha=5 \%$

**) significant at $\alpha=10 \%$

The finding of the significant volatility spillover in the stock market intra-ASEAN-5 supports the hypothesis by many researchers. The transmission of shocks is possible because of the dependence of normal cross-market among the countries that are in one regional area. The results of this research are in line with Jebran (2014), Jan and Jebran (2015), Jebran and Iqbal (2016a), Islam et al. (2014), and Li and Giles (2015). They found that the local markets were more competitive than the regional market. Most recently, Jebran et al. (2017) studied the Asian stock markets and found linkages among the markets.

In an era of the globalized economy, countries that have an integrated financial market in the region's economy have to avoid the contagion effect. It is because asset prices or fundamental economic variables from these countries will move in tandem.

With the increasing implementation of AEC, movement of goods, services, and capital becomes increasingly free to enter the ASEAN countries. Therefore, the financial markets and capital markets in the ASEAN region become increasingly integrated. The movement of the flow of goods in the ASEAN-5, since the year 2008, has shown a trend that continues to rise. In the ASEAN market, it is dominated by five countries namely Singapore, Malaysia, Indonesia, Thailand, and Philippines. Within the framework of the AEC, the liberalization of ASEAN capital flows is facilitated by the work of two committees. First, it is Working Committee on Capital Market Development (WC-CMD). It facilitates the development and integration of capital markets in ASEAN. Second, it is one of the main pillars. It is facilitated by the committee to help the exchange and settlement linkage through several stages of pure information linkage, linkage of electronic trading, and trade with centralized trading and settlement linkage.

\section{CONCLUSIONS}

By observing volatility spillover of the stock market in five ASEAN countries, it can indicate that the turmoil in the market will have an impact on stock markets in other countries. In this case, the significant spillover occurs from Singapore, Malaysia, Thailand, and Philippines Stock Exchange to Indonesia Stock Exchange. The data analysis result shows that the intensity of spillover also generally increases after December 2015 along with the increase in the intensity of economic integration within the framework of the AEC. Spillover intensity increases after the implementation of the AEC from Singapore, Malaysia, and Philippines Stock Exchange.

Significant spillover between stock exchanges in ASEAN-5 causes performance among the stock exchanges in the region to be correlated with one another. For investors who have a diversified portfolio in the stock market instruments across markets/ countries, the correlation between the stock market index performances is important in the framework of portfolio formation decision. In portfolio formation, investors in many models are assumed to be riskaverse. They focus on maximizing expected return with a certain level of risk that they can bear or form a portfolio that offers the lowest risk with a certain return. Diversification in the portfolio is intended to produce benefits such as reduced risk. Following the model of Markowitz, the benefit of diversification is a function of the correlation in the portfolio. Thus, the increase in asset returns with a positive correlation between stock market indices is caused by volatility spillover. It will lead to decreasingly diversification benefits to be obtained by investors who conduct cross-border diversification. Thus, information about how the turmoil in the market will be transmitted to market finance in other countries will be important for investment decisions in the global market.

From the aspect of the macroeconomy, the significant observed volatility spillover is strongly associated with the financial market system. The stability of the financial system is a condition that allows the national financial system to function effectively and efficiently. It can withstand internal and external vulnerabilities, which can contribute to the growth and stability of the national economy. The systemic risk that can shake the stability of the financial system does not necessarily come from elements within the domestic financial system, but it can also originate from shock outside the financial system. One of the turmoils is transmitted from the external stock exchange.

The findings of this research strengthen the results of the previous researchers related to the volatility spillover phenomenon. There should be an early warning system for the monetary and financial authority that is the turbulence in the external market, especially between the ASEAN region. It will be a source of systemic risk that can threaten the stability of the financial system in Indonesia. Valuable lessons from the experience of the crisis of 2008 are not to be complacent and let the crisis come without readiness. In an increasingly integrated regional economy, strong economic fundamentals are needed to maintain economic resilience from external shocks. 
Moreover, this research does not examine and compare the intensity of spillover volatility when the regional economy is in the normal phase and the crisis phase. By using a dynamic conditional correlation model, the future researchers detect the pattern of intensity movements of correlations between markets in the normal phase and crisis phase in the regional/ global economy.

\section{ACKNOWLEDGEMENT}

This research was supported by a grant from the Atma Jaya Catholic University of Indonesia in 2016. The researchers are indebted to the Faculty of Economics and Business at the Atma Jaya Catholic University of Indonesia which provided a grant to assist with this research.

\section{REFERENCES}

ASEAN. (2015). ASEAN Economic Community (AEC) 2025: Financial integration in ASEAN. Retrieved from http://www.bsp.gov.ph/downloads/ Publications/FAQs/ASEAN.pdf

Atje, R., \& Titiheruw, I. S. (2016). ASEAN capital market integration: The way forward. Retrieved from https://www.csis.or.id/publications/asean-capitalmarket-integration-the-way-forward

Bae, K. H., \& Zhang, X. (2015). The cost of stock market integration in emerging markets. Asia-Pacific Journal of Financial Studies, 44(1), 1-23. https:// doi.org/10.1111/ajfs.12079

Beck, T., Claessens, S., \& Schmukler, S. L. (2013). Financial globalization and crises: Overview. In The evidence and impact of financial globalization. Boston: Elsevier.

Brooks, C. (2014). Introductory econometrics for finance. New York: Cambridge University Press.

Islam, M. A., Islam, M. R., \& Siddiqui, M. H. (2014). Stock market volatility: Comparison between Dhaka Stock Exchange and Chittagong Stock Exchange. International Journal of Economics, Finance and Management Sciences, 2(1), 43-52. doi: 10.11648/j. ijefm.20140201.16.

Jan, W., \& Jebran, K. (2015). Empirical analyses of volatility spillover from G5 stock markets to Karachi Stock Exchange. Pakistan Journal of Commerce and Social Sciences (PJCSS), 9(3), 928-939.

Jebran, K. (2014). Dynamic linkages between Asian countries stock markets: Evidence from Karachi Stock Exchange. Research Journal of Management Sciences, 3(5), 6-13.

Jebran, K., Chen, S., Ullah, I., \& Mirza, S. S. (2017). Does volatility spillover among stock markets varies from normal to turbulent periods? Evidence from emerging markets of Asia. The Journal of Finance and Data Science, 3(1-4), 20-30. https://doi. org/10.1016/j.jfds.2017.06.001

Jebran, K., \& Iqbal, A. (2016a). Dynamics of volatility spillover between stock market and foreign exchange market: Evidence from Asian countries. Financial Innovation, 2(3), 1-20. https://doi.org/10.1186/ s40854-016-0021-1.

Jebran, K., \& Iqbal, A. (2016b). Examining volatility spillover between Asian countries' stock markets. China Finance and Economic Review, 4(6), 1-13. https://doi.org/10.1186/s40589-016-0031-1.

Li, Y., \& Giles, D. E. (2015). Modelling volatility spillover effects between developed stock markets and Asian emerging stock markets. International Journal of Finance \& Economics, 20(2), 155-177. https://doi. org/10.1002/ijfe.1506.

Saadah, S. (2013). Response asymmetry in spillover volatility: An empirical study in the Indonesia and Singapore Stock Market. Indonesian Capital Market Review, 5(2), 74-84. https://doi/org/10.21002/icmr. v5i2.1898.

Srivastava, A., Bhatia, S., \& Gupta, P. (2015). Financial crisis and stock market integration: An analysis of select economies. Global Business Review, 16(6), 11271142. https://doi.org/10.1177/0972150915604519.

Vieira, F. V. (2011). The new international financial crisis: Causes, consequences and perspectives. Brazilian Journal of Political Economy, 31(2), 217-237. http:// dx.doi.org/10.1590/S0101-31572011000200003. 